\title{
Development And Measurement Testing Physical Condition For Badminton Athletes U-15
}

\author{
Sesaria Nisa Afifi ${ }^{1}$, Sulaiman ${ }^{2}$, Setya Rahayu ${ }^{3}$, Ricko Irawan ${ }^{4}$ \\ \{sesariaafifi@gmail.com ${ }^{1}$ \} \\ Universitas Negeri Semarang. Indonesia ${ }^{1,2,3,4}$
}

\begin{abstract}
This research aims to produce physical test parameters for U-15 badminton athletes. Samples of this research are Djarum badminton club athletes of 13-15 years old total 27 men's athletes and total 23 women's athletes. Research method uses research and development ( $\mathrm{R} n \mathrm{D})$ approach with analysis descriptive percentage technique. The result : the assessment from the expert with average score 4,59 (very good). Validitas : 1) sit up : 91,7 (very high) 2), push up : 83,3 (very high), 3) balke: $75 \%$ (high), 4) sit and reach : 91,7 (very high), 5) sprint $20 \mathrm{~m}: 75 \%$ (high), 6) grip strength test : $75 \%$ (very high), 7) court agility test : $100 \%$ (very high), 8) vertical jump test : 100\% (very high) dan 3 steps medicine ball throw test : 91,7 \% (very high). Reliability: 0,917. Conclusion: validity of 7 test items is very high category and 2 item test is high category, meanwhile the reliability is very high. So this parameters can be used in PB. Djarum auditions for U$15 \mathrm{~s}$.
\end{abstract}

Keywords: Parameters, Physical condition, Badminton athletes U-15

\section{Introduction}

One of the biggest badminton club in Indonesia is PB. Djarum Kudus. PB. Djarum Kudus held auditions annually, the goal is to get the seeds of potential athletes. Badminton audition system commonly uses scout talent approach. Below are the tests to pass audition in the PB. Djarum Kudus, there are: 1) technique test, 2) physical test, and 3) psychological test. Physical capacity of badminton athletes is important to qualify on the audition (Ricko Irawan, 2016), while according Hetti, (2010: 46) badminton athletes is very important to have degree of excellent physical condition, because physical is the foundation of sport achievement and also good physical can maintain consistency of someone's performance when competing.

Physical condition test is conducted to gain data, which from the data we can see physical capacity rate of badminton athlete. Here are some kinds of physical tests for badminton athletes: (a) flexibility test (sit and reach), (b) speed test (sprint $30 \mathrm{~m}$ ), (c) leg muscle power test (vertical jump), (d) agility test (run 4 corners), (e) arm muscle power test (throwing a ball), (f) reaction test (step test), (g) endurance test (run $600 \mathrm{~m}$ ) (Utvi Hinda Zhannisa \& FX. Sugiyanto 2015).

Futhermore, component and physical classification of badminton sport according to (Albertus Fenanlampir \& Muhammad Muhyi Faruq, 2015:231) there are (a) strength test (hand dynamometer, back dinamometer \& leg dynamometer), (b) muscle endurance test (push up, sit up, squat jump), (c) speed test (sprint 50 meter), (d) flexibility test (flexometer), (e) power test (medicine ball put, vertical jump), and (f) heart and lungs endurance test (run 15 minutes VO2max). Meanwhile according to (Basri Yusuf, 2014:13) physical test for 
badminton athletes has 6 test points, there are: (a) endurance (VO2Max beep test), (b) speed coordination (court agility test), (c) power (vertical jump test), (d) coordination (skipping rope test), (e) core stability (sit-up test), (f) strength (push up test).

PB. Djarum Kudus become a center of talented young athletes in the badminton sport were then recruited through this audition. Audition system is as an effort to increase human resources in Indonesia, especially in the field of sport, is the focus and orientation of sports development as early as possible by doing the coaching and development of sport for young people from an early age (Basri Yusuf, 2014: 10). In the preliminary observations, researcher conducts FGD (Focus Group Discussion) consisting of technical coaches, physical trainers, and IT experts related with audition systems in the PB Djarum Kudus badminton. In that discussion, obtained the finding that physical tests which are tested at PB. Djarum Kudus audition is still not specific to age categories U-15s badminton athletes. In addition, management value of physical tests are still done manually.

In this case the talented athlete identification activities in the PB. Djarum Kudus audition need software and physical test parameters for U-15 badminton athletes so it is expected that result of audition in PB. Djarum Kudus get seeds of potential athletes.

\section{Methods}

This study uses research and development (R \& D) Sugiyono (2015: 407). The development of research used to produce a product of physical test parameters, and physical tests assessment software of U-15s badminton athlete. Physical test parameters include sit-up test, push-up test, balke test, sit and reach test, sprint 30 meters, grip strength test, court agility test, vertical jump test, three step medicine ball throw test.

The technique which is used is purposive sampling. It is selecting sample based on the criteria $U-15$ s badminton at $13-15$ years old.

After doing the analysis, so the researcher conducts the developmental model or product by doing test that have been compiled before. After the model is created then the next step is a test of the variables which already determined by researcher in order to ensure the success of the product that would be created.

This study uses tests and measurements design as trial. The design of this trial through two phases, namely a small group of test PB. Pendowo Semarang, PB. Sehat Semarang and PB. Hammas Semarang consists of 20 people, 13 male and 7 female with time allocation 1 meeting, and a large group test about products assessment parameters of large-scale physical tests performed on athletes PB. Djarum total 31 people consists of 14 male athletes and 17 female athletes categorized U-15s aged 13-15 years with 1 time allocation meeting.

Trial was conducted to get some important informations about revision and how effective products and the benefits of the developed products. This trial use some of subjects, such as: (a) physical expert (Drs. Moh Nasution, M.Kes), (b) badminton coach (Drs. Hermawan Pamot R, M.Pd) (c) badminton coach (Tahron, S.Pd., M.Pd.), (d) IT expert 1 (Fransiska Suryaning Pertiwi, M.Kom), IT expert 2 (Rismowati, S.Pd, M.Si), and IT expert 3 (Mohammad Irham Akbar, S.Si). 


\section{Results and Discussion}

The development of initial products were obtain from previous studies through interview, review literatures, and FGD (Focus Group Discussion).

Next, after getting information through research field, the researcher did review literature related with previous studies and hold FGD to get further data with Ricko Irawan 2014 research as orientation to arrange physical test parameters for U-15 badminton athletes.

Previous research was about profile of PB Djarum athletes' physical condition which produce 6 physical test categorizes to evaluate physical condition of female athletes to Pelatnas. Below were the results of previous research: (1) endurance measured with beep test; (2) speed measured with court agility; (3) power measured with vertical jump; (4) coordination measured with skipping rope; (5) abdominal muscle strengh measured with sit up and (6) strengh endurance measured with sit up.

Those 6 test items were used as researcher orientation to develop initial products which have been disscussed with some experts in FGD before. Some experts who was invited in FGD were 6 people: 3 badminton experts and 3 software experts

After doing small scale trial, the researcher did field trial. It could be seen in the table below:

Tabel 1. The results of badminton coach assessment about product significance with physical test assessment parameters.

\begin{tabular}{|c|c|c|c|c|c|c|c|c|}
\hline \multirow{2}{*}{ No. } & \multirow{2}{*}{$\begin{array}{l}\text { Aspek yang } \\
\text { dinilai }\end{array}$} & \multirow{2}{*}{ Parameter tes } & \multicolumn{5}{|c|}{ Skala penilaian } & \multirow{2}{*}{$\begin{array}{c}\text { Jumlah } \\
\text { responden }\end{array}$} \\
\hline & & & 5 & 4 & 3 & 2 & 1 & \\
\hline 1 & & & 1 & 2 & & & & 3 \\
\hline 2 & & & 2 & 1 & & & & 3 \\
\hline 3 & & & 2 & 1 & & & & 3 \\
\hline 4 & & & 1 & 2 & & & & 3 \\
\hline 5 & & & 2 & 1 & & & & 3 \\
\hline 6 & & & 2 & 1 & & & & 3 \\
\hline 7 & & & 2 & 1 & & & & 3 \\
\hline 8 & & & 2 & 1 & & & & 3 \\
\hline 9 & & & 2 & 1 & & & & 3 \\
\hline & total & & 16 & 11 & & & & 27 \\
\hline & persentage & & 59 & 41 & & & & $100 \%$ \\
\hline
\end{tabular}

Based on the large scale trial of U-15 badminton athletes physical test parameters on table 1 showed that total value from scale 5 (excellent) were 16 with total percentage $59 \%$. Beside that. total value of scale 4 (good) were 11 with total percentage $41 \%$. So, it can be concluded from large scale trial to physical test parameters about arrangement of badminton physical test instruments for U-15s has high significance. The validity of physical test parameters reviewed from sit up test with percentage $91,7 \%$ valid, push up test with persentage $83,3 \%$ valid, balke test 15 menit with persentage $75 \%$ valid, sit and reach test with persentage $91,7 \%$ valid, tes sprint $20 \mathrm{~m}$ with persentage $75 \%$ valid, tes grip dynamometer with persentage $75 \%$ valid, tes 
court agility with persentage $100 \%$ valid, vertical jump test with persentage $100 \%$ valid, midicine ball test with persentage $91,7 \%$ valid. The realibility of those 9 test items valued 0.974 could be said the reliability is very high.

The comparation between sit up test of 13-15 years old PB. Djarum athletes and sit up test of 13 - 15 years old Pengcap PBSI Pekalongan athletes. on Panji Mardiko research (2010:46). PB. Djarum athletes have average sit up test 69.5 meanwhile PBSI Pekalongan athletes have average sit up test 32. 71. Based on the result. it can be concluded that quality of abdominal muscle endurance PB. Djarum athletes is better than Pengcap Pekalongan athletes. Research result of Catur Magalhaes (2013) also stated that male badminton athletes of PB. Remaja Rembang regency age 14-16 years old have average sit up test 22.6 and deviation standard 3.05. If it was compared with PB. Djarum athletes who have average sit up test 69.5 and deviation standard 19.19. It could be concluded that quality of abdominal muscle endurance PB. Djarum athletes is better than PB. Remaja Rembang athletes.

In the research of Rona Lageayem. push up test has validity contribution 0.719 and reliability 0.632. if it was compared with validity push up test PB. Djarum 0.833 and reliability 0.974 means that validity and reliability of $\mathrm{PB}$. Djarum athletes are more convincing rather than other badminton athletes.

On aji kusuma's research. the average endurance of PB. Bintang timur athletes aged 1114 years old was 38.87. It was compared with aerobic endurance of PB. Djarum was 54.27. It reveals that the average endurance of PB. Djarum athletes is higher. so physical test endurance is appropiate to become physical test parameters.

The research of Giri Prayogo. flexibility gave great contribution $48.81 \%$ towards lob. it was related with physical test of PB. Djarum on sit and reach test which $\mathrm{v}=0.917$ and $\mathrm{r}=$ 0.974. Means it is appropiate when flexibility become one of physical test parameters on the competition of entering PB. Djarum athletes.

Madsen research. The elite group was significantly faster in the badminton-specific speed test with a best time of $32.3 \pm 1.1$ seconds compared with the skilled players $(34.1 \pm 2.0$ seconds) and non-badminton players (35.7 \pm 1.7 seconds). whereas there were no differences between groups in the $30-\mathrm{m}$ sprint test. It can be concluded that PB. Djarum athletes are special athletes which have been selected strictly. So. the result of physical test Djarum athletes is appropiate to be used as physical test parameters.

Grip strength has high significance on playing badminton. As stated in the study of Javian Abier Viven that grip muscle strength contributes to badminton. Male grip strength greater than female grip strength and dominant hands has greater power than non dominant hands. It can be concluded that tests of strength could be used in arrangement of PB. Djarum physical test parameters.

Zhannisa Utvi research said the average of agility at Ukm PGRI athletes 15.20 to 16.19 . When compared with the average of agility test at PB Djarum athlete was 11.35 . So the agility quality of PB. Djarum athletes is higher than Ukm PGRI athletes. We can conclude the results of agility physical tests PB. Djarum athlete can be used as parameter for auditions enter PB. Djarum athletes aged 13-15 years old because it has high standard.

Ishak Muhammad research strengthens the validity and reliability of explosive power test which obtained from PB. Djarum athletes was $r=0.974$ and $y=0.917$. In this study. obtained the explosive power contribution to badminton smash was $69.4 \%$. See the contribution. we can conclude that there is significant correlation between the test results of explosive power PB. Djarum athlete at the age of 13-15 years.

Heri Yogo Prayadi research explained there was significance between arm power and badminton training methods. For the category of high arm power. the appropiate training 
method was drilling method and lower arm power was appropiate using playing method. This means that arm power could be used in arrangement of physical test parameters.

\section{Conclusion}

Has composed parameters of physical test for U-15s badminton athletes aged 13-15 years in order to enroll the audition of PB. Djarum Kudus with assessment component as follows: sit up. push up. balke test 15 minutes. sit and reach. sprint 20 meter. grip strength test. vertical jump test. 3 steps medicine ball throw test. \& court agility test. As well as a reference national athletes in the assessment and measurement of the physical condition at the age of 13-15 years. 


\section{References}

[1] ....(2007). Undang- undang RI No 3 Tahun 2005 Tentang Sistem Keolahragaan Nasional. Kementrian.Negara Pemuda dan Olahraga Republik Indonesia.

[2] Abián-Vicén, J., Del Coso, J., González-Millán, C., Salinero, J. J., \& Abián, P. (2012). Analysis of dehydration and strength in elite badminton players. PloS one, 7(5), e37821.

[3] Aji Kusuma, P. R. A. N. A. T. A. (2015). Analisis Daya Tahan Aerobik Maksimal (Vo2max) Dan Anaerobik Pada Atlet Bulutangkis Usia 11-14 Tahun PB. Bintang Timur Surabaya Menjelang Kejurnas Jatim 2014. Jurnal Kesehatan Olahraga, 3(2).

[4] Basri Yusuf. 2014. Kriteria dan Parameter Fisik Atlet Masuk Pelatnas dan Atlet Pelatnas. Jakarta.

[5] Hetti, R. A. (2010). Sejarah Olahraga Bulutangkis. Bogor: Quadra.

[6] Irawan R. 2016. Profile Physical Condition of Women Badminton Athletes Djarum Badminton Club in the 2014 National Team Selection. Proceding Asean Council of Physical Education and Sport. Philippines: Pearlemont Hotel, Cagayan de Oro City, 2-5 September $2017 \mathrm{pp}$.

[7] Ishak, M. (2011). Kontribusi Daya Ledak Lengan, Kelentukan Pergelangan tangan dan Kelincahan Kaki Terhadap Pukulan Smash Dalam Permainan Bulutangkis Pada Siswa SMA Negeri 2 Bantaeng. Jurnal Competitor, 2(3), 93-104.

[8] KONI SUMUT. (2014). Data Hasil Pertandingan. Pekan Olahraga Provinsi Sumatera Utara 2014. Medan.

[9] Kristiyanto, A. (2010). Penelitian Tindakan Kelas (PTK) Dalam Pendidikan Jasmani dan Kepelatihan Olahraga. Surakarta: UNS Press Surakarta.

[10] Madsen, C. M., Karlsen, A., \& Nybo, L. (2015). Novel speed test for evaluation of badminton-specific movements. The Journal of Strength \& Conditioning Research, 29(5), 1203-1210.

[11] Magalhaes, C., \& Catur, D. A. N. I. E. L. (2013). Survei Kondisi Fisik Atlet Putra Usia 14-16 Tahun Pb. Remaja Kabupaten Jombang. Jurnal Prestasi Olahraga, 1(1).

[12] Prayogo, G. (2016). Kontribusi Daya Ledak Otot Lengan Dan Kelentukan Terhadap Pukulan Lob Atlet Bulutangkis PB. Merah Putih Kota Padang. Motion: Journal Research of Physical Education, 7(2), 203-212.

[13] Rona Legeayem, T. A. Y. S. (2018). Kontribusi Kekuatan Otot Lengan, Otot Perut, Otot Kaki, Dan Power Kaki Terhadap Jumping Smash Pada Bulutangkis. Jurnal Prestasi Olahraga, 2(1).

[14] Sugiyono. 2015. Metode Penelitian Pendidikan (Pendekatan Kuantitatif, Kualitatif dan R\&D). Penerbit CV. Alfabeta: Bandung.

[15] Zhannisa, U. H., \& Sugiyanto, F. X. (2015). Model tes fisik pencarian bakat olahraga bulutangkis usia di bawah 11 tahun di DIY. Jurnal Keolahragaan, 3(1), 117-126.

[16] Zhannisa, U. H., Royana, I. F., Prastiwi, B. K., \& Pratama, D. S. (2018). Analisis kondisi fisik tim bulutangkis Universitas PGRI Semarang. Journal Power Of Sports, 1(2), 30-41. 